\title{
Glycinebetaine improves salt tolerance in vinal (Prosopis ruscifolia Griesbach) seedlings
}

\author{
Diego A. Meloni ${ }^{*}$ and Carlos A. Martínez ${ }^{2}$ \\ ${ }^{1}$ National University of Santiago del Estero, Faculty of Agronomy and Agroindustries, Av. Belgrano (S) 1912, (4200) \\ Santiago del Estero, Argentina. \\ ${ }^{2}$ Department of Biology, FFCLRP, University of São Paulo, Av. Bandeirantes 3900, 14040-901, Ribeirão Preto, São \\ Paulo, Brazil.
}

*Corresponding author: dmeloni@unse.edu.ar

Received: 20 April 2009; Accepted: 04 November 2009.

\begin{abstract}
Glycinebetaine (GB) is a very important organic osmolyte that accumulates in a number of diverse groups of plants in response to environmental stress. In some plants, increased resistance to drought, salinity and low temperature has been achieved through exogenous application of GB. In this study, the effect of exogenously applied GB (8 mM) on the ability of vinal (Prosopis ruscifolia G.) plants to withstand $\mathrm{NaCl}$ stress was investigated. The dry biomass of vinal showed a decrease under salt stress, but in GBtreated plants exposed to the same stress, this reduction was mitigated. Sodium accumulated in the leaves of plants grown under saline conditions, but the addition of $\mathrm{GB}$ to salt-grown plants reduced $\mathrm{Na}^{+}$content by $40 \%$. Salinity significantly reduced the $\mathrm{K}^{+}$ concentration in leaves to $65 \%$ that of non-salinized controls. In the presence of $\mathrm{GB}$, leaf $\mathrm{K}^{+}$was comparatively higher, reaching as much as $90 \%$ of the control concentration. The sodium: potassium ratio in leaves was significantly higher in salt-stressed plants, but this ratio was lowered significantly by the addition of GB. When compared to control plants, $\mathrm{NaCl}$ stress increased malondialdehyde (MDA) concentrations by $95 \%$, but GB application reduced the MDA concentration in these same NaCl-treated plants. In comparison to control plants, the activity of superoxide dismutase (SOD) increased by $52 \%$ in salt-stressed plants. The addition of GB to salttreated plants stimulated SOD activity twice that of the non-salizined control. These results suggest that, in addition to protecting membranes, GB-enhanced salinity tolerance in vinal may involve an antioxidant mechanism involving enhanced SOD activity and improving the ion homeostasis under conditions of high salinity.
\end{abstract}

Key words: lipid peroxidation, salt stress, superoxide dismutase.

\section{RESUMO}

Glycinabetaine incrementa a tolerância a estresse salino em plântulas de vinal (Prosopis ruscifolia Griesbach): Glycinabetaína (GB) é um dos osmólitos orgânicos mais importantes que se acumulam em diversas plantas em resposta a estresses ambientais. Em algumas espécies, 0 aumento a resistência à seca, salinidade ou baixa temperatura foram conseguidos pela aplicação exógena da GB . Neste estudo foi investigado o efeito de GB aplicado exogenamente (8 $\mathrm{mM}$ ) na habilidade do vinal (Prosopis ruscifolia Griesbach) para suportar 0 estresse salino induzido por $\mathrm{NaCl}$. A biomassa seca das plantas diminuiu por efeito do tratamento salino, mas aumentou em plantas tratadas com GB. 0 Sódio $\left(\mathrm{Na}^{+}\right)$acumulou-se nas folhas das plantas crescidas sob estresse salino, mas a adição do GB às plantas tratadas com $\mathrm{NaCl}$ provocou uma diminuição de $40 \%$ no conteúdo de $\mathrm{Na}^{+}$. Em comparação às plantas controle, nas plantas tratadas com NaCl observou-se uma redução de $65 \%$ no conteúdo de potássio $\left(\mathrm{K}^{+}\right)$. Na presença do $\mathrm{GB}$, a concentração de $\mathrm{K}^{+}$nas plantas sob estresse salino foi maior que nas plantas não tratadas com GB. A relação sódio: potássio aumentou significativamente 
nas plantas sob estresse salino, mas esta relação foi reduzida significativamente pela adição de GB. Quando comparado às plantas controle, o estresse induzido pelo $\mathrm{NaCl}$ aumentou a concentração do malondialdehyde (MDA) em 95\%, mas a aplicação do GB reduziu a concentração de MDA em plantas tratadas com NaCl, indicando menor dano nas membranas. Em comparação às plantas controle, a atividade da superóxido dismutase aumentou em $52 \%$ nas plantas tratadas com NaCl. Em comparação ao controle, a adição do GB provocou um aumento de 100\% na atividade da SOD nas plantas sob estresse salino. Estes resultados sugerem que, além do aumento na proteção de membranas, 0 incremento da tolerância à salinidade em plantas de vinal por efeito do tratamento com GB pode estar relacionado com 0 aumento na proteção enzimática do estresse oxidativo gerado pelo estresse salino por meio da estimulação da atividade da SOD e potencialização da homeostase iônica sob estresse salino.

Palavras-chave: peroxidação de lipídeos, estresse salino, superóxido dismutase.

\section{INTRODUCTION}

Environmental stresses including drought, salinity and extremes of temperature are currently the major constraints that reduce crop yields worldwide. Salinity, in particular, is the most widespread problem, affecting approximately $20 \%$ of the world's cultivated land and nearly half of the area under irrigation (Flowers and Yeo, 1995). Salt stress can directly or indirectly affect the physiological status of plants by disturbing their metabolism, growth, development and productivity (Zhu, 2001).

Tolerance to salt stress is a very complex matter at the levels of both the whole plant and the cell (Ashraf and Harris, 2004). Therefore, the development of plants with tolerance to salt stress requires, among other things, a clear understanding of the genetic and physiological mechanisms that control the traits contributing to salt tolerance at different stages of plant development (Zhu, 2001). In the past two decades, biotechnological research has provided important insights into the molecular mechanisms of stress tolerance in plants (Rontein et al., 2002). Several studies have shown that different environmental stresses may induce osmotic stress, oxidative stress and protein denaturation in plants, which lead to cellular adaptive responses such as accumulation of compatible organic solutes, detoxification of reactive oxygen species and induction of stress proteins (Zhu, 2001).

One of the biochemical changes that occur when plants are subjected to biotic or abiotic stress is the production of reactive oxygen species (ROS) (Bray et al, 2002). The generation of ROS in plant tissues is a response commonly observed in salt-stressed plants (Mittler, 2002; Vaidyanathan et al., 2003; Azevedo-Neto et al., 2006).
The mitochondria and the chloroplasts are important intracellular generators of ROS (Asada, 1999). In the absence of any protective mechanisms, ROS can seriously disrupt normal metabolism through oxidative damage to lipids, proteins and nucleic acids (Rout and Shaw, 2001). To remove ROS, plant cells possess an antioxidant system consisting of low-molecular weight antioxidants, as well as antioxidant enzymes such as superoxide dismutase (SOD) (Rout and Shaw, 2001).

Environmental stresses including water deficit, salinity and low temperature can induce a significant accumulation of compatible solutes, a variety of small organic metabolites that are very soluble in water and non-toxic at higher concentrations (Bohnert et al., 1995). Generally, compatible solutes such as proline, sucrose, trehalose and polyols, and quaternary compounds such as glycinebetaine, protect plants from stress through different mechanisms, which include contributions to cellular osmotic adjustment, acceleration of reactive oxygen species scavenging systems, protection of membrane integrity, and stabilization of enzymes/ proteins (Ashraf and Foolad, 2007). Compatible solutes were originally thought to function as cytosolic osmotica involved in cellular osmoregulation (Hasegawa et al., 2000; Meloni et al., 2004). Consistent with this view, the increase in cellular osmolality that results from the accumulation of non-toxic, osmotically active solutes is accompanied by a reduced efflux of water from cells or even an influx of water into them, thus providing the turgor pressure necessary for cell expansion (Wyn Jones and Storey, 1978). However, the measured levels of many compatible solutes often appear to be too low to act as osmolytes (Chen and Murata, 2002; Sakamoto and Murata, 2002) unless they are restricted to an intracellular compartment. It is now apparent that the 
functions of compatible solutes are not as straightforward as initially believed (Hasegawa et al., 2000; Cuin and Shabala, 2005).

One of the most extensively studied compounds related to the tolerance of salt stress is glycinebetaine (GB). Levels of GB accumulation are correlated with the extent of salt tolerance by plants (Rhodes and Hanson, 1993). In Prosopis alba, endogenous GB increased from 3 to $21 \mu \mathrm{mol} \mathrm{g} \mathrm{DM}{ }^{-1}$ when plants were exposed to $300 \mathrm{mmol} \mathrm{m}^{-3} \mathrm{NaCl}$, suggesting that GB increases may be important for osmotic adjustment in Prosopis under salt stress (Meloni et al., 2004). However, the mechanisms of such amelioration are not fully understood. Exogenous application of GB to plants that accumulate little or none of this compound may help reduce the adverse effects of environmental stress (Yang and Lu, 2005; Ashraf and Foolad, 2007). For example, in maize, exogenously applied GB improved growth, leaf water content, net photosynthesis, and the apparent quantum yield of photosynthesis of the stressed plants (Yang and Lu, 2005).

In addition to its direct protective roles either as an osmoprotectant or through positive effects on enzyme and membrane integrity (Gorham, 1995), GB may also have a role in $\mathrm{Na}^{+} / \mathrm{K}^{+}$discrimination, which contributes to plant salt tolerance. Foliar application of GB on rice plants alleviated salt-induced inhibition of shoot growth. Moreover, under salt stress, GB-treated plants had significantly lower $\mathrm{Na}^{+}$ concentrations and higher $\mathrm{K}^{+}$concentrations in shoots compared with untreated plants (Rahman et al., 2002). Ion homeostasis in plants is governed by various membrane transport systems. Ion transport processes are central to the understanding of the complex and multigenic nature of salt tolerance in crop plants (Tyeman and Skerret, 1999). Imposition of salt stress results in a massive efflux of $\mathrm{K}^{+}$from plant cells (Chen et al., 2005) and a significant reduction of the intracellular pools of $\mathrm{K}^{+}$(Cuin et al., 2003). Low concentrations of exogenous GB significantly reduced $\mathrm{NaCl}$-induced $\mathrm{K}^{+}$efflux from barley roots in a dose-response manner (Cuin and Shabala, 2005).

Compared with other forest trees, Prosopis species are considered to be very salt-tolerant trees because they can grow at salinities approximately equal to that of seawater (Rhodes and Felker, 1987; Velarde et al., 2003). Vinal (Prosopis ruscifolia G.) is a native legume tree from the arid and semiarid regions of the phytogeographic area known as Chaco Occidental (Argentina), which is comprised of approximately 100 million hectares (Giménez and Moglia, 2003). Although soil salinization in some regions of Chaco Occidental is a severe problem for agriculture, the weedy Prosopis ruscifolia (vinal), with its $15 \mathrm{~cm}$ long thorns, rapidly colonizes frequently flooded and/or saline areas (Morello et al, 1971) and it is considered to be a salt-tolerant species (Velarde et al, 2003). Therefore, vinal provides a good model for studying the mechanisms of plant adaptation in environments with high salt concentrations.

In this study, the effect of exogenously applied GB on the ability of vinal (Prosopis ruscifolia $\mathrm{G}$.) plants to withstand $\mathrm{NaCl}$ stress was investigated, and we tested the hypothesis that GB can confer salt stress tolerance on vinal. Our results suggest that GB-enhanced salinity tolerance in vinal may involve an increase in SOD activity, maintenance of $\mathrm{K}^{+}$homeostasis by preventing $\mathrm{NaCl}$-induced $\mathrm{K}^{+}$leakage, and reduction of lipid peroxidation-linked membrane deterioration.

\section{MATERIALS AND METHODS}

Plant material and growth conditions: Seeds of vinal (Prosopis ruscifolia), kindly provided by the Laboratory of Seed Analysis, National University of Santiago del Estero, Argentina, were chemically scarified with concentrated sulfuric acid for 10 min and then washed under flowing tap water. Before sowing, seeds were rinsed three times in distilled water and placed in sterile paper rolls saturated with distilled water. The rolls were kept at $25^{\circ} \mathrm{C}$ with a $16 \mathrm{~h}$ photoperiod. Uniformly germinated seeds were selected and grown in pots containing aerated 25\% Hoagland's solution. Plants were grown at a quantum flux density of $350 \mu \mathrm{mol} \mathrm{m}^{-2} \mathrm{~s}^{-1}$ and $55 \pm 5 \%$ relative humidity. After 30 days, plants were divided into four groups. In the first and the second groups, seedlings were provided with $8 \mathrm{mM}$ glycinebetaine (GB) for 4 days and then exposed to 0 or $400 \mathrm{mM} \mathrm{NaCl}$, respectively. In the third group, 400 $\mathrm{mM} \mathrm{NaCl}$ was applied alone. The remaining group served as a non-treated control. $\mathrm{NaCl}$ was added to the growth medium in $50 \mathrm{mM}$ increments every $24 \mathrm{~h}$ until the final concentration of $400 \mathrm{mM}$ was reached. The concentrations of $8 \mathrm{mM}$ GB and $400 \mathrm{mM} \mathrm{NaCl}$ were chosen following preliminary optimization experiments (data not shown). After 14 days, plants were harvested for analysis of growth, mineral composition and biochemical effects. 
Determination of inorganic solute levels: For $\mathrm{Na}^{+}$and $\mathrm{K}^{+}$quantification, the plant material was dried in an oven at $80^{\circ} \mathrm{C}$, finely ground and digested with a nitric-perchloric acid mixture. The $\mathrm{Na}^{+}$and $\mathrm{K}^{+}$concentrations of the mineral extract were determined using a flame photometer.

Lipid peroxidation: Lipid peroxidation was estimated by measuring the amount of malondialdehyde (MDA) produced by the thiobarbituric acid reaction (Møller et al., 2007), as described by Hendry et al. (1993).

Activity of superoxide dismutase: For enzyme extractions, $0.4 \mathrm{~g}$ leaf samples were homogenized with ice cold $50 \mathrm{mmol} \mathrm{L}^{-1}$ sodium phosphate buffer ( $\mathrm{pH} \mathrm{6.8)}$ containing $1 \mathrm{mmol} \mathrm{L}^{-1}$ EDTA.Na $_{2}$ and 2\% (w/v) PVPP. The whole extraction procedure was carried out at $4^{\circ} \mathrm{C}$. Homogenates were then centrifuged at $13,000 \mathrm{~g}$ for 40 min at $4^{\circ} \mathrm{C}$ and supernatants were used for determination of enzyme activity. Protein concentration was determined according to the method described by Bradford (1976), using bovine serum albumin as a standard. Superoxide dismutase (EC 1.15.1.1) activity was estimated spectrophotometrically at $560 \mathrm{~nm}$ as the inhibition of photochemical reduction of NBT (Beauchamp and Fridovich, 1971). Three milliliters of reaction mixture contained $33 \mu \mathrm{M}$ NBT, $10 \mathrm{mM}$ L-methionine, $0.66 \mathrm{mM}$ EDTA. $\mathrm{Na}_{2}$ and $0.0033 \mathrm{mM}$ riboflavin in $0.05 \mathrm{M} \mathrm{Na}$ phosphate buffer ( $\mathrm{pH} 7.8$ ). One unit of SOD was defined as the amount of enzyme that inhibits $50 \%$ NBT photoreduction. Reactions were carried out at $25^{\circ} \mathrm{C}$ under a light intensity of $300 \mu \mathrm{mol} \mathrm{m} \mathrm{m}^{-2} \mathrm{~s}^{-1}$ for $10 \mathrm{~min}$.

Plant harvest and measurements: After $14 \mathrm{~d}$ of growth, plant growth was evaluated by measuring the dry weight (DW) of vinal seedlings.

Statistical analysis: The experimental design was fully randomized. Each treatment consisted of five replicates. All data obtained were subjected to one way analysis of variance (ANOVA). The mean differences were compared by the Tukey test at a 0.05 confidence level.

\section{RESULTS}

Under conditions of salt stress, plant DW decreased by $35 \%$ in comparison to unstressed control plants (Figure 1). However, exogenously applied GB increased the DW of saltstressed plants by $16 \%$ in comparison to the group treated with $\mathrm{NaCl}$ alone. GB application to control plants decreased the plant DW by $6 \%$.

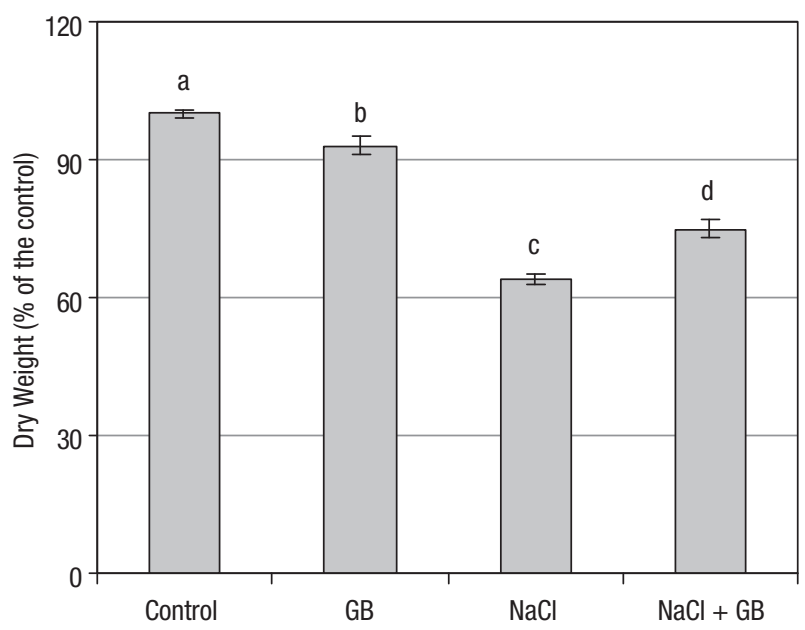

Figure 1. Effect of exogenous glycine betaine (GB) on dry weight of $\mathrm{NaCl}-$ treated vinal seedlings. Different letters indicate significant differences by Tukey's Test at $5 \%$. Values are the mean \pm SD $(n=5)$.

Stressed vinal plants accumulated significantly less $\mathrm{Na}^{+}$and more $\mathrm{K}^{+}$upon application of GB (Figure 2). Salinity significantly increased $\mathrm{Na}^{+}$concentration in these leaves to $100 \%$ of that of non-salinized controls (Figure 2A). However, addition of $\mathrm{GB}$ to $\mathrm{NaCl}$-stressed plants reduced $\mathrm{Na}^{+}$concentration by $40 \%$. Salinity significantly reduced leaf $\mathrm{K}^{+}$concentration to $65 \%$ of that of non-salinized controls. In the presence of $\mathrm{GB}$, leaf $\mathrm{K}^{+}$ concentration was higher, equivalent to $90 \%$ that of the controls (Fig 2B). No effects of $\mathrm{GB}$ on leaf $\mathrm{Na}^{+}$or $\mathrm{K}^{+}$concentrations were observed in control plants. The sodium: potassium (Na:K) ratio in leaves was significantly increased (to approximately $220 \%$ of that of control plants) after the exposure of plants to $\mathrm{NaCl}$ stress, but the addition of GB to salinized plants decreased $\mathrm{Na}: \mathrm{K}$ to $50 \%$ that of control plants (Figure $2 \mathrm{C}$ ). 

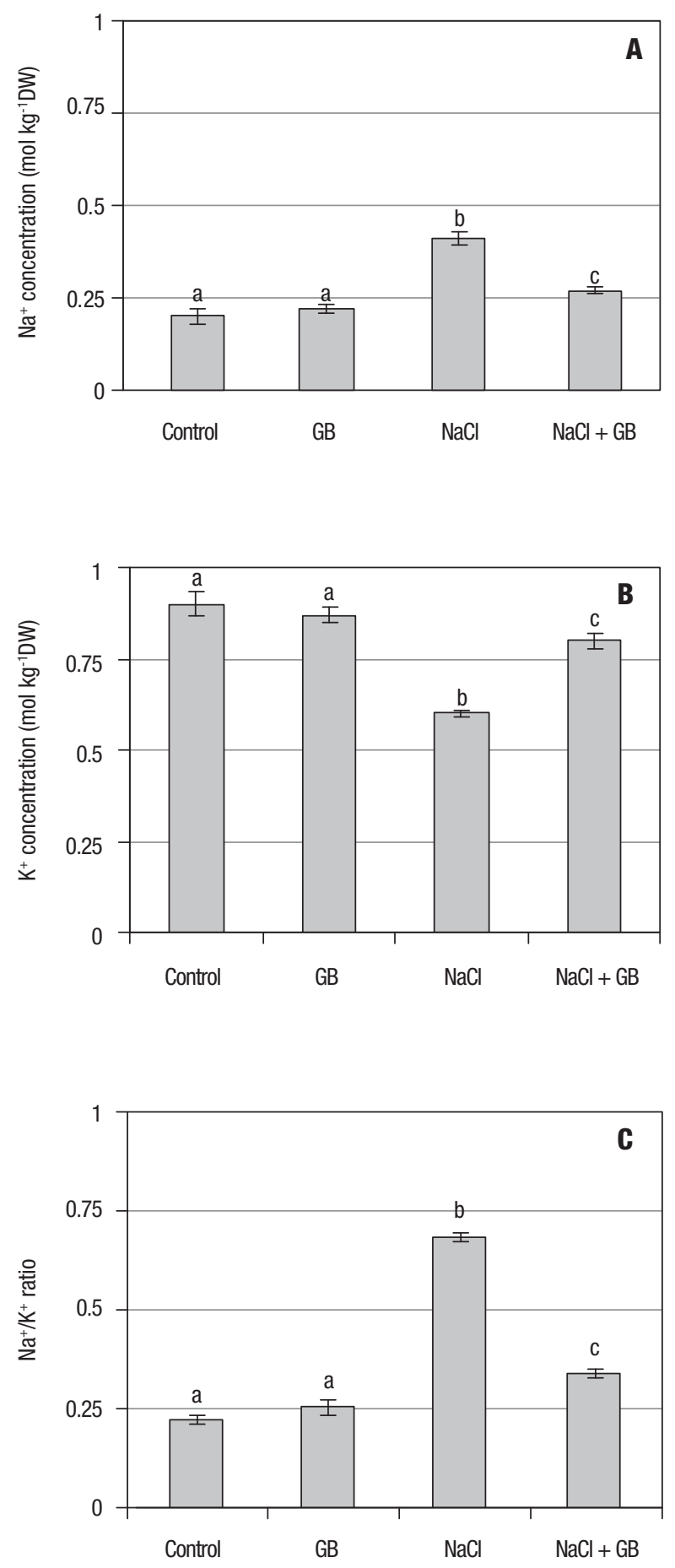

Figure 2. Effect of exogenous glycine betaine (GB) on $\mathrm{Na}^{+}(A), \mathrm{K}^{+}(\mathrm{B})$ concentrations and $\mathrm{Na}^{+} / \mathrm{K}^{+}$ratio (C)in leaves of $\mathrm{NaCl}$-treated vinal seedlings. Different letters indicate significant differences by Tukey's Test at $5 \%$. Values are the mean $\pm \operatorname{SD}(n=5)$.
Malondialdehyde (MDA) levels were used to asses the extent of membrane damage caused by salt stress. In NaClstressed plants, MDA levels were approximately 2-fold higher than in unstressed control plants (Figure $3 \mathrm{~A}$ ). However, the application of GB to salinized plants caused a significant, $40 \%$ reduction of MDA levels in leaves compared with the $\mathrm{NaCl}-$ stressed plants.

To assess the role of GB on the detoxification of reactive oxygen species, we determined the activity of superoxide dismutase (SOD), a key enzyme of the reactive oxygen species scavenging system. SOD activity in $\mathrm{NaCl}$-stressed plants was about $52 \%$ higher than in the unstressed control plants. However, GB application to salinized plants increased levels of SOD activity to $100 \%$ that of control plants (Figure 3 B).
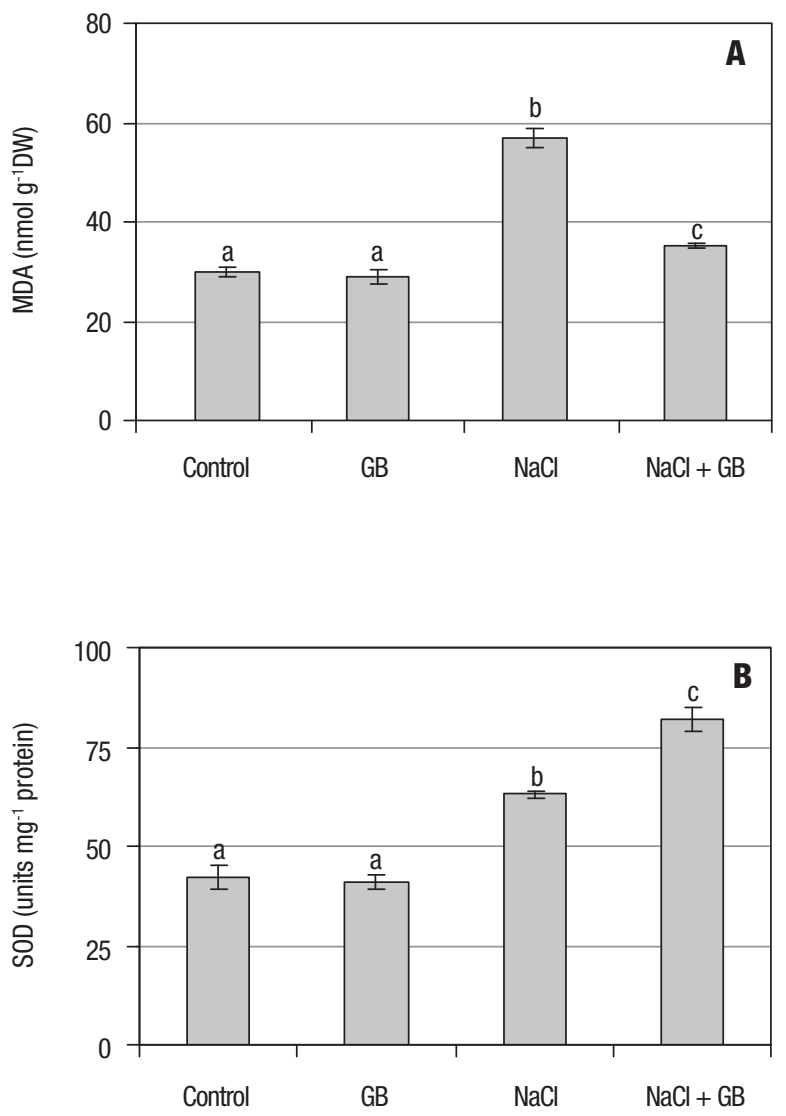

Figure 3. Effect of exogenous glycine betaine (GB) on malondialdehyde concentrations (A) and superoxide dismutase (SOD) activity (B) in leaves of $\mathrm{NaCl}$ - treated vinal seedlings. Different letters indicate significant differences by Tukey's Test at $5 \%$. Values are the mean $\pm S D(n=5)$. 


\section{DISCUSSION}

Shrubs and trees of the genus Prosopis naturally occur in saline environments throughout the tropical and subtropical arid and semi-arid areas of the world, and they are considered to be very salt-tolerant plants because they can grow at approximately seawater salinities (Rhodes and Felker, 1987; Velarde et al., 2003). Glycinebetaine (GB) appears to play an important role in the response of plant cells to a variety of stresses (Sakamoto and Murata, 2002). Current research efforts are focused on the elucidation of the mechanisms by which GB protects the cellular machinery in vivo and how, as a result, it enhances the tolerance of whole plants to environmental stress (Cuin and Shabala, 2007). In a previous work (Meloni et al., 2004), we found that an increase in endogenous GB levels may be important for osmotic adjustment in Prosopis alba under salinity stress. At $300 \mathrm{mmol} \mathrm{L}^{-1} \mathrm{NaCl}$, the $\mathrm{GB}$ content in these plants increased 5-fold and 6.8-fold in roots and leaves, respectively, as compared with the unstressed control. However, in another experiment, we determined that endogenous levels of GB in $P$. ruscifolia (around $5 \mathrm{mM}$ ) did not increase under salt stress (data not shown).

Turgor pressure reductions in expanding tissues, reductions in photosystem activity and direct effects of accumulated salt on critical metabolic steps in dividing and expanding cells are the three physiological mechanisms that have often been considered to be primarily responsible for the growth inhibition induced by salinity (Newman, 1997). In the present work, a small but significant reduction in plant DW was observed in non-salinized plants in the presence of GB. Heuer (2003) and Demiral and Türkan (2006) also found decreased fresh weight after GB application in seedlings of tomato and rice, respectively, confirming our results. It seems that addition of GB alone slightly affects the growth of vinal seedlings and that the protective effect of GB is apparent only under conditions of salt stress. It is generally accepted that the increase in cellular osmolality that results from the accumulation of nontoxic, osmotically active solutes such as $\mathrm{GB}$ is accompanied by the influx of water into, or at least a reduced efflux of water from, cells, thus providing the turgor pressure necessary for cell expansion (Hare et al., 1998).

In this work, $\mathrm{NaCl}$-stressed vinal plants accumulated significantly more $\mathrm{Na}^{+}$and less $\mathrm{K}^{+}$than unstressed control plants. Conversely, application of GB to salt-stressed plants resulted in a reduction in $\mathrm{Na}^{+}$concentration and an increase in $\mathrm{K}^{+}$concentration when compared to $\mathrm{NaCl}$-stressed plants (Figure 2). Modulation of ion fluxes is amongst the earliest cellular events in response to abiotic stress (Knight and Knight 2001). One of the most affected components is $\mathrm{K}^{+}$ transport, with a massive $\mathrm{K}^{+}$efflux from cells reported in response to numerous environmental stresses (Shabala, 2003). In light of the strict requirement for $\mathrm{K}^{+}$homeostasis in the cell cytosol (Leigh, 2001), such a massive $\mathrm{K}^{+}$efflux would undoubtedly affect the growth, metabolic performance and survival of the plant.

Salinity tolerance is typically characterized by augmented exclusion of $\mathrm{Na}^{+}$and increased absorption of $\mathrm{K}^{+}$to maintain the proper $\mathrm{Na}^{+} / \mathrm{K}^{+}$balance in shoots. Considering the $\mathrm{K}^{+}$ retention seen in salt-tolerant cells, the ameliorating effect of $\mathrm{GB}$ on $\mathrm{NaCl}$ - induced $\mathrm{K}^{+}$efflux would have significant consequences for the salt tolerance of the plant. Thus, by decreasing the $\mathrm{NaCl}$-induced $\mathrm{K}^{+}$efflux, the tolerance of vinal to salinized conditions could be improved by supplying very low levels of exogenous GB to the plant. Exogenous application of $G B$ to rice plants growing under salt stress resulted in reduced $\mathrm{Na}^{+}$accumulation and the maintenance of $\mathrm{K}^{+}$concentrations in the shoot (Lutts, 2000). In a number of studies carried out with transgenic plants engineered to express higher levels of $\mathrm{GB}$, the levels of accumulated GB were rarely more than $1 \mu \mathrm{mol}$ $\mathrm{g}^{-1}$ FW (Holmström et al., 2000; Huang et al., 2000). This is far too low for conventional osmorregulation, even assuming that all of these solutes are located in the cytosol. There is general agreement that the transgenic production of compatible solutes can protect plants from stress to some extent, even when they are present at low and osmotically insignificant levels (Sakamoto and Murata, 2002). Since the maintenance of high cytosolic $\mathrm{K}^{+}$concentrations is considered to be one of the most fundamental salt tolerance mechanisms in plants (Maathuis and Sanders, 1999), our current data indicate that this acquired tolerance may be the result of mitigation of $\mathrm{NaCl}$ induced $\mathrm{K}^{+}$efflux. In agreement with these results, Cuin and Shabala (2005) reported that root preincubation in 3 or $5 \mathrm{mM}$ GB resulted in an increase in salt-induced $\mathrm{H}^{+}$efflux in barley. Increased $\mathrm{H}^{+}$efflux will hyperpolarize the plasma membrane and, hence, will contribute to better $\mathrm{K}^{+}$retention in plant cells. The increase in proton pumping may enhance $\mathrm{K}^{+}$uptake (Shabala and Lew, 2002) and provide a driving force for the plasma membrane $\mathrm{Na}^{+} / \mathrm{H}^{+}$exchanger to move $\mathrm{Na}^{+}$from the cytoplasm into the apoplast (Ayala et al., 1996), contributing to improved $\mathrm{K}^{+}: \mathrm{Na}^{+}$ratios in plant tissues. 
Glycinebetaine may reduce stomatal opening and decrease the transpiration rate, thus leading to the decrease in $\mathrm{Na}^{+}$accumulation in shoots (Raghavendra and Reddy, 1987). Rahman et al. (2002) observed that root tips and root cap cells of rice plants treated with GB alone produced numerous vacuoles, which did not develop in the control plants. They hypothesized that these vacuoles act as storage vessels for $\mathrm{Na}^{+}$in the roots, resulting in a decrease of $\mathrm{Na}^{+}$transportation to the shoot. Understanding the specific ionic and molecular mechanisms underlying the regulation by compatible solutes, $\mathrm{K}^{+}$and $\mathrm{H}^{+}$transport across the plasma membrane may be critical for increasing the efficiency of the mode of action of salt-tolerant crops.

GB application reduced lipid peroxidation levels, thereby alleviating the damaging effects of salt treatment on membrane lipids. Peroxidation of membrane lipids in higher plants reflects free radical-induced oxidative damage at the cellular level under conditions of salt stress. A remarkable increase in the lipid peroxidation levels in the leaves of saltstressed vinal and a significant decrease in lipid peroxidation in salt-stressed, GB-treated plants suggest that exogenous GB application can largely protect vinal against salt-dependent oxidative damage. These results are in strong agreement with the results of Demiral and Türkan (2004) who found decreased levels of lipid peroxidation in rice that was supplied with GB when exposed to salt stress. Membranes, and their integral and associated components used for the uptake and distribution of ions and solutes, are considered to be determinants for developing stress-resistant crops. Low concentrations of glycinebetaine can improve salt and cold stress tolerance, possibly by protecting photosynthetic protein complexes (Holmström et al., 2000) and by reducing the lipid peroxidation of cell membranes (Chen et al., 2000).

An increase in the activity of superoxide dismutase, ascorbate peroxidase, glutathione reductase, catalase, and peroxidases in response to salinity stress, as well as higher antioxidant activity in tolerant species/varieties, have been reported (Abreu et al., 2008; Meloni et al., 2003; Sairam and Srivastava, 2002; Smirnoff, 2005). Our results suggest that the reduction of lipid peroxidation in salinized GB-treated plants could be explained in part by the enhanced SOD activity induced by GB. The ability of compatible solutes to scavenge free radical species has been widely reported (Bohnert et al. 1995; Noctor and Foyer 1998; Niyogi 1999; Hong et al. 2000).
However, most of these results have been obtained in vitro or under physiologically high concentrations of osmolytes. Thus, the involvement of compatible solutes in ROS signaling and the regulation of membrane transport in planta remain to be shown. Recently, Cuin and Shabala (2007) found that low (5 $\mathrm{mM}$ ) concentrations of compatible solutes (glycine betaine, proline, mannitol, trehalose or myo-inositol) significantly reduces $\mathrm{OH}^{*}$-induced $\mathrm{K}^{+}$efflux, similar to previous reports for $\mathrm{NaCl}$-induced $\mathrm{K}^{+}$efflux (Cuin and Shabala, 2005). Importantly, a significant reduction in $\mathrm{K}^{+}$efflux was found using osmolytes with no reported free radical scavenging activity, as well as those for which a role in free radical scavenging has been demonstrated. This indicates that in addition to free radical scavenging, compatible solutes must play other roles, possibly of a regulatory nature, in mitigating the damaging effects of oxidative stress. Further studies are required in order to elucidate the mechanism by which GB regulates SOD activity. Genomic approaches promise extraordinary amounts of information about all osmotically induced genes (Cushman, 2001). Recently, Chen et al (2009) used a proteomic and bioinformatic approach to determine that improvement of salt tolerance in tomato might be achieved through the exogenous application of compatible solutes such as GB. The quantitative and qualitative analysis of differentially expressed tomato proteins under salt stress, based on computational bioinformatics, revealed three major regulating networks: photosystem II (PSII), Rubisco and SOD.

In conclusion, the results of this study suggest that GBenhanced salinity tolerance in vinal (Prosopis ruscifolia G.) may involve the maintenance of $\mathrm{K}^{+}$homeostasis by preventing $\mathrm{NaCl}$-induced $\mathrm{K}^{+}$leakage, reduction of lipid peroxidation-linked membrane deterioration, and an increase in SOD activity, a key enzyme of the reactive oxygen species scavenging system.

Acknowledgements: This research was supported by the Consejo de Investigaciones Científicas y Tecnológicas of the Universidad Nacional de Santiago del Estero (CICyT -UNSE), Argentina. CAM is a CNPq fellowship.

\section{REFERENCES}

Abreu CEB, Prisco JT, Nogueira ARC, Becerra MA, F. de Lacerda C, GomesFilho $E$ (2008) Physiological and biochemical changes occurring in dwarfcashew seedlings subjected to salt stress. Braz. J. Plant Physiol. 20:105118.

Asada K (1999) The water-water cycle in chloroplasts: Scavenging of active oxygen and dissipation of excess photons. Annu. Rev. Plant Physiol. Plant Mol. Biol. 50:601- 639. 
Ashraf M, Harris PJ (2004) Potential biochemical indicators of salinity tolerance in plants. Plant Sci. 166:3-16.

Ashraf M, Foolad MR (2007) Roles of glycine betaine and proline in improving plant abiotic stress resistance. Environ. Exp. Bot. 59:206-216.

Ayala F, O' Leary JW, Schmaker KS (1996) Increased vacuolar and plasma membrane $\mathrm{H}^{+}$-ATPase activities in Salicornia bigelovii Torr in response to $\mathrm{NaCl}$. J. Exp. Bot. 47:25-32.

Azevedo- Neto AD, Prisco JT, Enéas-Filho J, Abreu CEB, Gomes-Filho E (2006) Effects of salt stress on antioxidative enzymes and lipid peroxidation in leaves and roots of salt-tolerant and salt-sensitive maize genotypes. Environ. Exp. Bot 56:87-94

Beauchamp C, Fridovich I (1971) Superoxide dismutase: improved assays and applicable to acrylamide gels. Anal. Biochem. 44:276-287.

Bohnert HJ, Nelson DE, Jensen RG (1995) Adaptations to environmental stresses. The Plant Cell 7:1009-1111.

Bradford MM (1976) A rapid and sensitive method for the quantitation of microgram quantities of protein utilizing the principle of protein-dye binding. Anal. Biochem. 72: 248-254.

Bray E., Bailey-Serres J., Weretilinyk, E. (2002). Responses to Abiotic Stresses. In: Buchanan, B; Gruissem, W., Jones, R. (Eds.): Biochemical and Molecular Biology of Plants. ASPB, John Wiley \& Sons, pp. 1158-1202

Chen WP, Li PH, Chen THH (2000) Glycine betaine increases chilling tolerance and reduces chilling-induced lipid eroxidation in Zea mays L. Plant Cell Environ. 23: 609-618.

Chen THH, Murata N (2002) Enhancement of tolerance of abiotic stress by metabolic engineering of betaines and other compatible solutes. Curr. Opin. Plant Biol. 5:250-257.

Chen Z, Newman L, Zhou M, Mendham N, Zhang G, Shabala S (2005) Screening plants for salt tolerance by measuring $\mathrm{K}^{+}$flux: a case study for barley. Plant Cell Environ. 28:1230-1246.

Chen S, Gollop N, Heuer B (2009) Proteomic analysis of salt-stressed (Solanum lycopersicum) seedlings: effect of genotype and exogenous application of glycinebetaine. J. Exp. Bot. 60:2005-2009.

Cuin TA, Miller AJ, Laurie SA, Leigh R (2003) Potassium activities in cell compartments of salt-grown barley leaves. J. Exp. Bot. 54:657-661.

Cuin TA, Shabala S (2005) Exogenously supplied compatible solutes rapidly ameliorate NaCl-induced potassium efflux from barley roots. Plant Cell Physiol. 46:1924-1933.

Cuin TA, Shabala S (2007) Compatible solutes reduce ROS-induced potassium efflux in Arabidopsis roots. Plant Cell Environ.30:875-885.

Cushman JC (2001) Osmoregulation in plants: Implications for agriculture. Amer. Zool. 41: 758-769.

Demiral T, Türkan I (2004) Does exogenous glycinebetaine affect antioxidative systemof riceseedlingsunderNaCltreatment?J.PlantPhysiol.161:1089-1100.

Demiral T, Türkan I (2006) Exogenous glycinebetaine affects growth and proline accumulation and retards senescence in two rice cultivars under $\mathrm{NaCl}$ stress. Environ. Exp. Bot. 36:29-38.

Flowers TJ, Yeo AR (1995) Breeding for salinity resistance in crop plants: where next? Aust. J. Plant Physiol. 22:875-884.

Giménez AM, Moglia JG (2003) Árboles del Chaco Argentino. Guía para el reconocimiento dendrológico. Editorial El Liberal, Argentina.

Gorham J (1995) Betaines in higher plants-biosynthesis and role in stress metabolism. In: Wallsgrove RM (Ed.), Amino Acids and Their Derivates in Higher Plants, pp.172-203. University Press, Cambridge, UK.

Hare PD, Cress WA, Van Staden J (1998) Dissecting the roles of osmolyte accumulation during stress. Plant Cell Environ. 21:535-553.

Hasegawa PM, Bressan RA, Hu JH, Bohnert HJ (2000) Plant cellular and molecular responses to high salinity. Annu. Rev. Plant Physiol. Plant. Mol. Biol. 51:463-499.
Hendry GAF, Thorpe PC, Merzlyak MN (1993) Stress indicators- lipid peroxidation. In: Hendry GAF, Grime JP (Eds.), Methods in Comparative Plant Ecology, pp. 154-156. Chapman and Hall, London, UK.

Heuer B (2003) Influence of exogenous application of proline and glycine betaine on growth of salt-stressed tomato plants. Plant Sci. 165:696-699.

Holmström KO, Somersalo S, Mandal A, Pavla ET, Welin B (2000) Improved tolerance to salinity and low temperature in transgenic tobacco producing glycine betaine. J. Exp. Bot. 51:177-185.

Hong ZL, Lakkineni K, Zhang ZM, Verma DPS (2000) Removal of feedback inhibition of D1-pyrroline-5-carboxylate synthetase results in increased proline accumulation and protection of plants from osmotic stress. Plant Physiol. 122:1129- 1136.

Huang J, Hirji R, Adam L, Rozwadokssi Kl, Hammerlindl JK, Keller WA, Selvaraj $\mathrm{G}$ (2000) Genetic engineering of glycine betaine production toward enhancing stress tolerance in plants: genetic limitations. Plant Physiol. 122:744-756.

Knight H, Knight MR (2001) Abiotic stress signalling pathways: specificity and cross-talk. Trends Plant Sci. 6:262-267.

Leigh RA (2001) Potassium homeostasis and membrane transport. J. Plant Nutr. Soil Sci. 164:193-198.

Lutts $S$ (2000) Exogenous glycine betaine reduces sodium accumulation in salt-stressed rice plants. Int. Rice Res. Notes 25:39-40.

Maathuis FJM, Sanders D (1999) $\mathrm{K}^{+}$nutrition and $\mathrm{Na}^{+}$toxicity: the basis of cellular $\mathrm{K}^{+} / \mathrm{Na}^{+}$ratios. Ann. Bot. 84:123-133.

Meloni DA, Oliva MA, Martínez CA, Cambraia J (2003) Photosynthesis and activity of superoxide dismutase, peroxidase and glutathione reductase in cotton under salt stress. Environ. Exp. Bot. 49:69-76.

Meloni DA, Gulotta MR, Matínez CA, Oliva MA (2004) The effects of salt stress on growth, nitrate reduction and proline and glycine betaine accumulation in Prosopis alba. Braz. J. Plant Physiol. 16:39-46.

Mittler R (2002) Oxidative stress, antioxidants and stress tolerance. Trends Plant Sci. 7:405-410.

Møller IM, Jensen PE, Hansson A (2007) Oxidative modifications to cellular components in plants. Annu. Rev. Plant Biol. 58:459-481.

Morello J H, Crudelli NE, Saraceno M. (1971) Los vinalares de Formosa (Republica Argentina) Instituto Nacional de Tecnologia Agropecuaria (INTA). Series Fitogeografica 11, p. 113.

Newman P (1997) Salinity resistance and plant growth revisited. Plant Cell Environ. 20: 1193-1198.

Niyogi KK (1999) Photoprotection revisited: genetic and molecular approaches. Annu. Rev. Plant Physiol. Plant Mol. Biol. 50:333-359.

Noctor G, Foyer CH (1998) Ascorbate and glutathione: keeping active oxygen under control. Annu. Rev. Plant Physiol. Plant Mol. Biol. 49:249-279.

Raghavendra AS, Reddy KB (1987) Action of proline on stomata differs from that of abscisic acid. G- substances or methyl jasmonate. Plant Physiol. 83:732-734.

Rahman M, Miyake H, Takeoka Y (2002) Effects of exogenous glycine betaine on growth and ultraestructure of salt-stressed rice seedlings (Oryza sativa L.). Plant Prod. Sci. 5:33-44.

Rhodes D, Hanson AD (1993) Quaternary ammonium and tertiary sulfonium compounds in higher plants. Annu. Rev. Plant Physiol. Plant Mol. Biol. 44:357-384.

Rhodes D, Felker P (1987) Mass screening Prosopis (mesquite) seedlings for growth at seawater salinity. Forest. Ecol. Manag. 24:169-176.

Rontein D, Basset G, Hanson AD (2002) Metabolic engineering of osmoprotectant accumulation in plants. Metab. Eng. 4:49-56.

Rout NP, Shaw BP (2001) Salt tolerance in aquatic macrophytes: possible involvement of the antioxidative enzymes. Plant Sci. 160:415-423. 
Sairam RK, Srivastava GC (2002) Changes in antioxidant activity in subcellular fractions of tolerant and susceptible wheat genotypes in response to long-term salt stress. Plant Sci. 162:897-904.

Sakamoto A, Murata N (2002) The role of glycine betaine in the protection of plants from stress: cues from transgenic plants. Plant Cell Environ. 25:163170.

Shabala S, Lew RR (2002) Turgor regulation in osmotically stressed Arabidopsis epidermal root cells. Direct support for the role of inorganic ion uptake as revealed by concurrent flux and cell turgor measurements. Plant Physiol.129:290-299.

Shabala S (2003) Regulation of potassium transport in leaves: from molecular to tissue level. Annals Bot. 92:627-634.

Smirnoff N (2005) Antioxidant and Reactive Oxygen Species in Plants. Blackwell Publishing, Oxford, UK.
Tyeman SD, Skerret LM (1999) Root ion channels and salinity. Sci. Hort. 78:175-235.

Vaidyanathan H, Sivakumar P, Chakrabarty R, Thomas G (2003) Scavenging of reactive oxygen species in NaClstressed rice (Oryza sativa L.) - differential response in salt-tolerant and sensitive varieties. Plant Sci. 165:1411-1418.

Velarde M, Felker P, Degano C (2003) Evaluation of Argentine and Peruvian Prosopis germplasm for growth at seawater salinities. J. Arid Environ. 55:515-531.

Wyn Jones RG, Storey R (1978) Salt stress and comparative physiology in Gramineae II. Glycine betaine and proline accumulation in two salt and waterstressed barley cultivars. Aust. J. Plant Physiol. 5:817-829.

Yang X, Lu C (2005) Photosynthesis is improved by exogenously glycine betaine in salt stressed maize plants. Physiol. Plant. 124:343-352.

Zhu JK (2001) Plant salt tolerance. Trends Plant Sci. 2:66-71. 